\title{
Consumers influence on the greening of distribution - exploring the communication between logistics service providers, e-tailers and consumers
}

Uni Sallnäs and Maria Björklund

The self-archived postprint version of this journal article is available at Linköping University Institutional Repository (DiVA):

http://urn.kb.se/resolve?urn=urn:nbn:se:liu:diva-167733

N.B.: When citing this work, cite the original publication.

Sallnäs, U., Björklund, M., (2020), Consumers influence on the greening of distribution - exploring the communication between logistics service providers, e-tailers and consumers, International Journal of Retail \& Distribution Management. https://doi.org/10.1108/IJRDM-07-2019-0213

Original publication available at:

https://doi.org/10.1108/IJRDM-07-2019-0213

Copyright: Emerald

http://www.emeraldinsight.com/ 


\title{
Consumers' influence on the greening of distribution - Exploring the communication between logistics service providers, e-tailers and consumers
}

\begin{abstract}
Purpose

This paper takes its starting point in the possibilities consumers have to influence the greening of distribution. It focusses on three key actors who can facilitate consumer influence, namely e-tailers, logistics service providers (LSPs), and the consumers themselves. The purpose is to illuminate consumers' possibilities to influence the greening of distribution by exploring the communication between LSPs, e-tailers, and consumers.

\section{Design/methodology/approach}

Website scans of the forty largest Swedish e-tailers and ten LSPs were combined with interviews of three e-tailers and three LSPs.

\section{Findings}

The findings suggest that consumers at present have limited possibilities to influence the greening of distribution. One reason for this is the limited communication between LSPs, etailers and consumers. A gap in communication arises because e-tailers determine how to promote distribution alternatives on their websites, while it is the LSPs who develop and offer green distribution services.
\end{abstract}

\section{Research limitations/implications}

This paper provides a first step in our understanding of what is needed in order to facilitate green distribution decisions from e-consumers.

\section{Practical implications}

E-tailers can gain an increased understanding of their important role as facilitators of environmentally sound decisions for consumers through their design of websites. This study also highlights the need for LSPs to support e-tailers in this work.

\section{Social implications}

The study contributes to the societal striving towards zero greenhouse gas emission by focussing on decreasing environmental effects by using suitable logistics.

\section{Originality/value}

In contrast with previous research into the environmental impact of e-commerce distribution, this study investigates the possibilities consumers have to influence green logistics within ecommerce.

Keywords: e-commerce distribution, last mile, e-tailers, environmental logistics, green supply chain management, communication 


\section{Consumers' influence on the greening of distribution - Exploring the communication between logistics service providers, e-tailers and consumers}

\section{Background}

E-commerce is growing and thus research interest in the field is also growing. Recent studies address, for example, value propositions in multi-channel settings (Yrjölä et al., 2018) and the impact of the delivery solutions offered on consumer behaviour (Xiao et al., 2018). An area of particular concern within e-commerce is the environmental impact of distribution (Mangiaracina et al., 2015). Browne et al. (2005) were early to show that transport from store to home by consumers is a very inefficient transport (from an energy perspective) in the product supply chain. However, the impact depends also on aspects such as the use of public transport and multi-purpose shopping (Wiese et al., 2015a). In a recent study on the movement of consumers (i.e. person transport) in an omnichannel context, Buldeo Rai et al. (2019a) find that people who shop online for delivery to the home, or to a pick-up point, generate the smallest $\mathrm{CO}_{2}$ footprint.

Several studies have set out to understand the environmental impact of e-commerce distribution (e.g. Edwards et al., 2010; Pålsson et al., 2017; van Loon et al., 2015). The results obtained differ, and depend on such factors as the scope of the research, its geographical context, and the return policies of the e-commerce practitioners (Buldeo Rai et al., 2019b; van Loon et al., 2015). A decrease in the environmental impact of e-commerce distribution is thus a challenge, and many actors must contribute. This paper focusses on three key actors who must be involved if change is to be realised, namely e-tailers, logistics service providers (LSPs), and consumers.

As many logistical operations have severe environmental impact (McKinnon, 2015; Weijers et al., 2012), it is easy to point to LSPs as the ones who are responsible for decreasing this impact, as they often carry out the deliveries within e-commerce. Actions have, indeed, been taken by LSPs to improve environmental sustainability (Colicchia et al., 2013), such as the use of more efficient engines and renewable fuels (Martinsen and Huge-Brodin, 2014). However, the logistics industry cannot drive change by itself. Instead, LSPs depend on how other actors in the supply chain, such as e-tailers (who are the customers of LSPs), and consumers (who generate large parts of the demand for distribution) act. Buldeo Rai (2019) suggests that the retailer makes a choice of the design of the distribution based on the offer from the LSP. The retailer then provides the consumer with a range of offers from which to choose. The environmental sustainability of last mile distribution is determined by the choices and offers made. In fact, retailers (and thus also e-tailers) have an important strategic role to play in ensuring sustainability, due to their position between suppliers and consumers, and due to their consolidation of bargaining power (Kotzab et al., 2011; Wiese et al., 2015b).

Customers, in turn, are an important driver for environmentally sustainable supply chains (see e.g. Meixell and Luoma, 2015; Sallnäs, 2016). Consumers are even sometimes perceived as the ones most responsible to solve the problem caused by their consumption (Evans et al., 2017). This would imply a decreased responsibility of LSPs and e-tailers to drive the development of green distribution. However, Wiese et al. (2015b) argue that retailers must behave responsibly if we are to reach sustainability in retailing, and that they must support their customers in behaving responsibly. In line with this, Buldeo Rai et al. (2019b) find that "consumers do not feel responsible for enhancing sustainability but instead expect businesses - including retailers and logistics service providers - to act in a sustainable way" (p. 43). As consumer behaviour has a large effect on the environmental impact of e-commerce distribution 
(van Loon et al., 2015; Wiese et al., 2015b), it is vital that actors, such as e-tailers and LSPs, facilitate sound consumer choices.

Despite the importance of the consumer, research into green logistics has largely examined the role of shippers and has maintained an upstream focus, while treating consumers and their preferences as a "black box" (Abbasi and Nilsson, 2012; Bask et al., 2013; Meixell and Luoma, 2015). Some exceptions are Buldeo Rai et al. (2019b), who study consumer preferences linked to distribution in omnichannel retailing, and van Loon et al. (2015), who include consumer behaviour in their analysis of the environmental impact of online retailing.

This paper takes its starting point in the possibilities that consumers have to influence the greening of distribution. Communication (Mohr and Nevin, 1990; Peters and Fletcher, 2004) between consumers and e-tailers plays a central role in these possibilities. In addition, the LSPs inevitably influence green distribution and affect these possibilities (e.g. Martinsen and HugeBrodin, 2014).

The purpose of this paper is to illuminate consumers' possibilities to influence the greening of distribution by exploring the communication between LSPs, e-tailers, and consumers.

\section{Frame of reference}

\section{Greening distribution activities}

Distribution of goods is a necessity for e-commerce to succeed, but in terms of environmental sustainability, it constitutes a large challenge. The distribution of goods has a negative impact on the environment in terms of, for example, climate change and the emission of hazardous particles (e.g. McKinnon, 2015). Several ways to reduce the environmental impact have been proposed. McKinnon and Woodburn (1996) were early to single out four interdependent levels of logistical decision making that influence the environmental impact of transport. The framework they proposed, includes most initiatives regarding environmentally sustainable distribution and is also relevant in an e-commerce context. Hübner et al. (2016) developed a framework for omnichannel distribution in grocery retailing that does not include aspects of sustainability, but still includes initiatives similar to the four levels presented by McKinnon and Woodburn (1996). This paper relies on these four levels, as well as two more environmental practices (eco-design and packaging) that can influence the environmental impact of e-commerce. The four interdependent levels are:

1. Structure of the logistical system, i.e. the number, location and capacity of hubs such as factories and terminals (McKinnon and Woodburn, 1996). In an e-commerce context, the location and number of picking and packing points for consumer orders for example relate to this level. In their striving to satisfy increasing demands for fast deliveries, e-tailers can, for example, re-evaluate the locations of warehouses (Allen et al., 2017). However, the structure of the logistics system has environmental implications. Decentralised logistics systems, for example, means shorter distances between the supply point and the consumer, which in turn is less environmentally damaging (Kohn and Huge-Brodin, 2008; McKinnon, 2015). However, centralised systems can enable a higher degree of consolidation and changes to more environmentally beneficial transport modes (Kohn and Huge-Brodin, 2008). The matter of centralised versus decentralised warehouses is a complicated one and the most environmentally beneficial solution is yet to be found (van Loon et al., 2014). Etailers without physical stores generally operate and distribute orders from a centralised warehouse to consumers (e.g. home delivery or pick-up points), while e-tailers with stores have options to distribute from the local shops to consumers and also to have consumers pick up their orders in the local shops (van Loon et al., 2015).

2. Patterns of sourcing and distribution, i.e. the supply and customer base that creates a need for freight transport both upstream and downstream in the supply chain. E-consumers can 
often choose between home delivery and collection at a pick-up point (Buldeo Rai et al., 2019). Notably, consumer trips and failed home deliveries both have a high impact on the environmental effects of e-commerce (Pålsson et al., 2017; van Loon et al., 2015). Delivery location (and its environmental impact) is one factor that could be included in the distribution offers of LSPs and e-tailers, as well as in the choices of consumers (Buldeo Rai, 2019).

3. Scheduling of production and distribution flows. The use of just-in-time transport and demands on time windows influences the frequency and size of the deliveries. E-consumers are typically given a choice about when they wish to receive their order, both in terms of delivery lead times (e.g. next-day delivery or five-day delivery) and delivery windows (e.g. afternoon or evening) (Buldeo Rai, 2019). Orders with short delivery lead times typically decrease the possibility of consolidation, and may thus lead to an increase in environmental impact (Allen et al., 2017). By choosing to wait an extra day or two, consumers can thereby affect the environmental impact of their purchase. Interestingly, e-tailers increasingly offer short delivery lead times to consumers (Buldeo Rai et al., 2019b). According to van Loon et al. (2015), orders are even sometimes split into two or more deliveries in order to speed up delivery lead times. The authors found that such splits have a larger environmental impact than if the order was to be delivered as one consignment, and suggest that e-tailers can encourage consumers to increase the number of items for their deliveries.

4. Management of transport resources, including decisions related to the choice of transport mode, vehicle technology, load factors, and routing. Examples of activities are mode selection (e.g. Björklund et al., 2016; McKinnon, 2015), the use of eco-driving, and the quality of vehicle maintenance (e.g. McKinnon, 2015; Weijers et al., 2012). Many LSPs now try environmentally sustainable modes of transport and vehicle types, such as bikes and electric vehicles (Buldeo Rai et al., 2019b), which can complement the use of the conventional, more environmentally damaging trucks. Indeed, transport mode and vehicle type are two factors that could be included in the distribution offers to consumers (Buldeo Rai, 2019), giving them a possibility to influence the environmental impact of their purchase.

Evangelista (2014), among others, has suggested that reverse logistics is an additional environmental practice in the transport industry that influences its environmental impact. Indeed, Pålsson et al. (2017) showed that product returns influence the energy efficiency of ecommerce distribution alternatives to a large extent. Perotti et al. (2012) and Colicchia et al. (2013) put forward the use of eco-design and packaging as examples of green supply chain practices, and the environmental relevance in e-commerce of such practices has been confirmed by Mangiaracina et al. (2015) and Pålsson et al. (2017).

\section{Communication}

Communication is important for the supplier to understand the buyers' needs and expectations, and for the buyer to understand the capabilities of the supplier (Cambra-Fierro and PoloRedondo, 2008). In this study, the LSP can be viewed as the supplier, and the consumer as the buyer. The retailer is supplier to the consumer and the buyer from the LSP.

Previous studies of communication in logistics have focussed mainly on information exchange and technology, and not on strategic communication issues (Richey, 2009). Communication is commonly described as "the glue that holds together a channel of distribution" (Mohr and Nevin, 1990, p. 36), and this description stresses the importance of communication between the actors in the supply chain. Previous studies in green logistics have proposed activities closely related to communication, such as collaborative planning 
(Evangelista, 2014; Perotti et al., 2012), and emission reports (Martinsen and Huge-Brodin, 2014).

Information sharing beyond dyads has many challenges, two of which are the weaker interdependence between actors, and the lack of a direct link between information sender and receiver (Kembro et al., 2017). These challenges depend on factors such as: trust, benefit sharing, information quality, the degree to which one player is dominant, and the level of confidentiality of the information.

Several researchers have suggested that supply chains benefit from shared information, but Kembro and Näslund (2014) were unable to find any studies that support these claims. They suggest that further research is necessary in which the supply chain is treated as a unit of analysis, in order to determine whether information sharing truly is a benefit. Kembro et al. (2017) have made a similar call for research to analyse how companies can overcome challenges in sharing information beyond the dyad.

Mohr and Nevin (1990) suggested a framework to help understand communication in marketing channels. Peters and Fletcher (2004) showed that this framework placed communication behaviour at the heart of channel performance, and that it helps to understand the outcomes of different communication behaviours. Mohr and Nevin (1990) singled out four important facets of communication, which have been classified in the present article as follows:

- Frequency, which describes the amount and duration of contact.

- Direction, which can be in two directions (when feedback is given, for example) or in one direction (often from the more powerful actor to the less powerful one).

- Formality, which describes how structured, planned, routinized and formal the communication is, and whether formal meetings and written modes are used. Communication can be formal or personalised informal communication. (This classification was described briefly by Mohr and Nevin (1990), but the terminology was first used by Mohr and Sohi (1995).)

- Content, which describes the type of information strategy embedded in the information exchanged. Direct communication strategies are designed to change the behaviour of the receiver by implying or requesting a specific action, while indirect communication aims to change the beliefs and attitudes of the receiver, without requesting any specific action.

Figure 1 is a conceptual overview of the six communication flows (and their facets of communication) regarding green distribution activities operationalised by the LSPs .

Insert Figure 1 around here.

\section{Methodology}

To address consumers' possibilities to influence the greening of distribution, we investigate the interfaces between consumers, e-tailers and LSPs. The empirical investigation comprised two research methods: website scans of e-tailers and LSPs, and interviews with representatives from e-tailers and LSPs.

The website scans

Firstly, we conducted a website scan to gain insight into how consumers can influence the greening of e-commerce distribution. This comprised a broad scan of the largest business-toconsumer (B2C) e-tailers in Sweden (based on turnover, and a list provided by Ehandelsindex, 2018). Sweden was selected due to: 1) the high level of maturity in the use of e-commerce 
among consumers on the European market (e.g. Eurostat, 2020); 2) a high consumer interest in sustainability (PostNord, 2019); 3) convenience in the selection of delivery address, as the authors of this paper are located in Sweden, and 4) language (the language on the e-tailers' websites is commonly adapted to a national consumer). Large e-tailers were selected as they have stronger bargaining power (Wiese et al., 2015) towards LSPs, and thus have more influence on the design of distribution. Turnover of the 40 e-tailers whose websites were scanned ranged from EUR 16 million to EUR 808 million.

One researcher conducted the website scan of all 40 companies. The second researcher independently conducted the website scan for the 10 largest companies, in order to determine whether the two researchers categorised the information in a similar manner. Only minor deviations were seen. Saturation was achieved after 40 e-tailers, as no new aspects of green distribution emerged. The e-tailers sell a wide range of products, such as clothing, furniture, home electronics, health and beauty products, and books and music. All of the e-tailers are primarily online-based and only some have physical stores.

Data were collected by acting as window shoppers, visiting the websites as consumers. Products were placed into the shopping cart, after which the visitor proceeded to the checkout. The purchase was, naturally, never finalised. One weakness of this method is that the distribution options sometimes depend on the delivery address. Customers in cities can generally choose between more services than those living in the countryside. We gave a postcode for delivery located in a large, but not the largest, city in Sweden.

All information related to distribution was noted, both the type of information and its location on the webpage. The information scan was coded into a Microsoft Excel table developed for this specific study. The table enabled collection of detailed information about green distribution based on the categorisation presented in the frame of reference. Specifically, the information about each company included e.g.: delivery lead times offered, delivery locations offered, the specific LSPs linked to each company's distribution offering, return policies and specifics about the, if present, green distribution alternatives. In order for a distribution alternative to be coded as "green distribution", e-tailers had to offer distribution services at the checkout that included words or symbols associated with environmental sustainability, such as green, environmental or climate offsets.

We also conducted a website scan to gain insight into how LSPs present their offers to etailers. The LSPs selected were the ones identified to offer deliveries to consumers on the scanned websites of the e-tailers. Ten LSPs were scanned, including some of the largest LSPs in Sweden as well as smaller LSPs that specialise in e-commerce distribution. As for the scan of e-tailers, attention was given to activities associated with green distribution, in accordance with those presented in the frame of reference.

\section{The interviews}

E-tailers who offered green distribution were identified during the website scan. These etailers were contacted, and two of them agreed to contribute to our study. In addition, colleagues who had been discussing green distribution with a certain company suggested that we contact it. Respondents who had strategic responsibility and who had taken an active part in developing the distribution-related services described on the webpages were selected from each company. We also sought additional respondents in the companies who could have supplementary information, but the persons interviewed claimed to be sufficient to provide information about green distribution. LSPs who were presented on the webpages of the e-tailers as being the ones who delivered the green logistics service were identified and contacted. We also asked the selected e-tailers and LSPs to identify the most ambitious actors in the field, which resulted in one additional actor and confirmation of some of the companies previously selected. Table 1 provides information about the selected companies. 


\section{Insert Table 1 around here.}

To increase the reliability of the interviews (Miles and Huberman, 1994), the questions were based on literature on green distribution and communication, and on information from the website scan. An interview guide was sent to all respondents prior to the interview, to increase the reliability of the information obtained (Bryman and Bell, 2011). Two interview guides were used: one for e-tailers and one for LSPs. Some questions were similar, such as the type of green distribution offered by the company, the drivers behind the offer of green distribution, and the perception of the company of which delivery locations and time from order to delivery are most purchased and the effect of these parameters on distribution. E-tailers were asked about the interfaces with both LSPs and consumers, whereas LSPs were asked mainly about the communication with e-tailers. The interviews were conducted by phone and lasted 30-60 minutes. Two researchers were involved in the interviews: one with main responsibility for asking questions, and one with main responsibility for taking notes. The interviews were recorded, and the recordings were used to produce write-ups. The interviewees were then given the opportunity to check the write-ups for accuracy and approve the contents.

\section{Results}

The results presented below have been structured in accordance with the frameworks identified in the literature review, i.e. the green distribution activities and the communication facets. For each framework, the three interfaces studied (the consumer - e-tailer interface; the e-tailer LSP interface; the LSP - consumer interface) are presented separately. The green distribution activities are presented below, while the results from the communication framework are shown in Table 2. Note that one green distribution activity is missing, as we found no evidence of the structure of the logistical system in the data sets. This is in line with findings of Buldeo Rai (2019), who also found no evidence of this activity in an e-commerce context. Note also that one additional green distribution activity has been added: emission offsets. These were a reoccurring finding on the homepages and identified as an important aspect of the green distribution in two of the interfaces (the consumer - e-tailer interface and the e-tailer - LSP interface).

\section{Green distribution activities in the consumer-e-tailer interface}

Patterns of sourcing and distribution: Consumers can typically select their preferred choice of delivery location (commonly home delivery either to the mailbox or to the door, or to a local pick-up point). One of the e-tailers has physical stores and offered the alternative of collecting orders at a local store. E-tailers are aware of trends in consumer behaviour and E-tailer A, for example, has seen an increase in demand for home deliveries when consumers are at home (6$10 \mathrm{pm})$. Communication is based on an offering from the e-tailer, and the consumer ticking a box. No environmental considerations are included in the communication.

Scheduling of production and distribution flows: Consumers can normally choose a desired delivery lead time (i.e. the estimated period between order and delivery), and it is usual to offer one quick option, such as "Within $24 \mathrm{~h}$ ", and one slower alternative, such as "Within 2-3 days". Most e-tailers charge extra for quick deliveries, and e-tailers see that demand for fast deliveries is rising. Whether this is due to the offer of such deliveries by e-tailers or a real demand for orders to arrive quickly is not clear. We contrast here two options: E-tailer B offers the fastest option, which costs more and includes climate offsets, as the default choice, while E-tailer C has placed a marginally slower environmental option (which includes distribution by train to some extent) first, and set this as the default choice. This has resulted in a large increase in the environmental option being selected, at the expense of the fastest distribution alternative. 
Management of transport resources: The websites contain very little about, for example, mode selection, vehicle technology and load factor. E-tailer $\mathrm{C}$ is an exception, as presenting the green delivery induces consumers to choose distribution by train to some extent, as described above. Notably, the actual meaning of "green distribution" is not communicated directly at the checkout, and the consumers must continue to browse on the website.

Reverse logistics: The process for returning goods may be of interest to consumers who buy online. Three options are widely used: 1) free returns, 2) conditional free returns (only when consumers need another product or size), or 3) consumer-paid returns. All of these are common in our sample. E-tailers appear to be aware of their ability to influence consumers, both from a sales perspective and an environmental perspective. The interviewed e-tailers are strictly against free returns, partially from an environmental perspective. This, however, probably depends on the nature of the product and the e-tailers studied here sell products that do not need to be tried out (such as shampoo and books). This means that they have very low return rates. It should be noted that all e-tailers must allow a 14-day cancellation right for consumers, but that they are not required to finance returns for cancelled orders.

Eco-design and packaging: Consumers are typically not given any information about packaging at the checkout when ordering online. However, all three e-tailers note that interest from consumers is increasing, as they all receive an increasing amount of feedback about packaging from consumers. Retailer A, for example, reports that customer support gets many questions about environmental issues, such as microplastics in products and plastic packaging material in their delivered packages. Retailer B has similar experiences, and one example given is when consumers receive packages filled to a small part with the ordered products and to a larger part with plastic packaging. This can cause consumers to react strongly and therefore contact customer support. Notably, packaging is the only green distribution activity communicated by consumers to the studied e-tailers.

Climate offsets: Most of the few examples of green distribution found on the websites include climate offsets. Some e-tailers choose to promote this at checkout. E-tailers do not want to complicate matters for consumers when they are ready to purchase products. An interesting example is presented by E-tailer B: The e-tailer's fast delivery option, which costs extra, also includes climate offsets. Previously, this bundled offer was presented at checkout as "green distribution". However, this made consumers believe that the environmental aspect of the offer caused the extra cost, when it, in fact, was the fast delivery that induced the cost. To avoid confusion, E-tailer B has chosen not to promote the climate offsets at checkout and, instead, inform consumers on the detailed pages about distribution conditions. The distribution service thus remains the same, but consumers might not be aware of the climate offsets.

\section{Green distribution activities in the e-tailer - LSP interface}

Patterns of sourcing and distribution: LSPs are typically either specialised in one type of delivery (for example home delivery) or has a range of services, such as delivery to pick-up points, home addresses or stores. Two of the three LSPs studied here expresse a wish to see greater use of pick-up points. This wish mainly arises from considerations of the resource bases and convenience, and not from environmental arguments. LSP C, in contrast, has decided to focus on home deliveries during the evenings, and expresses a wish that consumers choose this option more frequently.

Scheduling of production and distribution flows: The websites revealed that most LSPs can offer a range of delivery lead times, but some appeared to focus primarily on quick deliveries. According to LSP A, some e-tailers want to be able to offer a combination of green and fast distribution. LSP A does not offer such a service, and suggested that the concept is contradictory, since more rapid delivery often gives a higher environmental impact (Allen et al., 2017). Interestingly, LSP B offers such a service. This difference between the ideas of LSPs 
may cause problems in the communication between e-tailers and LSPs. Specifically, LSPs find it troublesome that e-tailers lack understanding of logistics, which complicates communication. Interestingly, no link between delivery lead times and environmental impact was found on the websites, suggesting that e-tailers are not given much help in understanding what facilitates green distribution.

Management of transport resources: Some e-tailers require LSPs to use environmentally sustainable vehicles or fuels. LSP C stated that e-tailers, in general, have a limited understanding of logistics systems, and stressed that it is good that e-tailers do not, in general, demand green distribution alternatives, such as certain types of fuel, in too much detail. It is better that they promote environmental work on a more general level and leave the details to the LSPs. When considering the management of transport resources, it is interesting to note the green distribution alternative offered by LSP A. The LSP denoted this as "more expensive technology", by which they stated that they invest in alternatives that cost extra (such as some forms of renewable fuel). Interesting to note is also that only one of the LSPs presented information about transport resources and their link to environmental impact on the websites.

Reverse logistics: LSPs charge e-tailers for returns made by consumers, which shows that the concept of "free returns" is driven and applied by e-tailers. LSP B even stressed that something needs to be done to decrease returns from consumers. However, the website scan revealed that LSPs commonly stress efficient handling of product returns in their offer to etailers.

Eco-design and packaging: LSPs and e-tailers communicate to a very small degree about eco-design and packaging, which suggests that these issues are handled by the e-tailers separately, without consideration of the demand of the logistics system. One exception is etailer A, who informs LSPs about the changing behaviour of consumers concerning the use of plastic packaging material.

Climate offsets: Climate offsets is the most commonly used green distribution activity offered to e-tailers on LSPs' websites. Further, communication about climate offsets differs somewhat, depending on LSP and e-tailer. Some e-tailers appear to demand that LSPs apply climate offsetting (E-tailer A and, to some extent, E-tailer B), but e-tailers do not have detailed insight into how these are applied. Interestingly, the LSPs have chosen different ways to communicate climate offsets to e-tailers. LSP B includes offsets in its green distribution service, while LSP C pays for climate offsets for all of its transports, but actively chooses not to promote this to e-tailers as green distribution. Furthermore, E-tailer B found the offset service offered by the LSP to be too expensive, and decided to handle this itself. It is, however, uncertain whether this lowered the cost, as the LSP should gain large-scale advantages on such expenses as administration.

\section{Green distribution activities in the consumer - LSP interface}

There is limited information exchange in the consumer-LSP interface. Nonetheless, two of the green distribution activities presented in the frame of reference can be linked to this interface:

Management of transport resources: LSP A is considering making its green distribution, which includes a small extra cost and supports the LSP's development within this green distribution activity, as the default option. This would force consumers to actively untick the box if they want a service that is not "green". This would only be possible, however, for the few e-tailers that are linked to LSP A's own system.

Scheduling of production and distribution flows. Some LSPs give consumers the possibility to choose a desired delivery window, thus increasing the likelihood of consumers being at home when orders are delivered. Some LSPs also offer consumers the possibility to follow truck movements in a mobile application, thus providing up-to-date information on a preliminary 
delivery time. LSP C, who specialises in home delivery in the evenings, is considering whether to improve its service by being more specific about the exact time it will deliver.

Insert Table 2 around here.

\section{Discussion}

The results presented here show that consumers have limited possibilities to influence the greening of distribution, and play a peripheral role. The study has thus shown that consumers are not always an important driver towards more environmentally sustainable supply chains, as previous work has suggested (see e.g. Meixell and Louma, 2015). However, e-tailers do adapt to some extent their green distribution alternatives to certain target groups, which suggests that consumers can play a role, albeit a passive one, in the greening of distribution. Etailer B, for example, stated that: "We believe that for our specific target group, environmental sustainability is a relatively important issue and therefore we want to offer services that are both adapted to our target group and as attractive as possible”. Nonetheless, a main finding of this study is that the influence that consumers have on the greening of distribution is low, and that a central reason for this is the limited communication between LSPs, e-tailers and consumers.

Many activities can contribute to the greening of distribution (e.g. McKinnon and Woodburn, 1996). Such activities are primarily linked to the LSPs, who perform the distribution activities. E-tailers and consumers can influence the activities conducted by LSPs through communication (see e.g. Martinsen and Huge-Brodin, 2014; Sallnäs, 2016). At the same time, LSPs should be able to influence the actions of e-tailers and consumers by communicating various offerings to these groups. This study shows, however, that the communication of green distribution activities is limited in the interfaces between LSPs, e-tailers and consumers. In particular, activities related to the second and third levels of distribution activities (i.e. patterns of distribution, and the scheduling of distribution flows) are those most often communicated to e-tailers and consumers. This communication is, however, often not presented as offering green distribution alternatives, but rather as general service offerings in terms of delivery location and delivery lead time. Without guidance from LSPs or e-tailers ( $2 \mathrm{~b}$ and $3 \mathrm{~b}$ in Figure 1), consumers have limited possibilities to green distribution, as they may have insufficient knowledge to assess environmental impact, which is far from intuitional (Pålsson et al., 2017; van Loon et al., 2015). The difficulty in assessing environmental impact raises an issue also for the communication between LSPs and e-tailers, as communication in both directions (3a and $3 \mathrm{~b}$ in Figure 1) will probably be necessary in order to offer clear green distribution alternatives to consumers. Communication from LSPs to e-tailers is unlikely to be sufficient, as e-tailers are customers of the LSPs and thus often have a power advantage (Sallnäs, 2016). E-tailers therefore can influence profoundly the types of green logistical activities included in their relationships with LSPs. Activities associated with the fourth level of the green distribution activities (i.e. management of transport resources) are, in contrast, easier to communicate, as consumers are already aware of some of the environmental benefits of choosing one option over another (train instead of truck, for example). However, we saw very little evidence of communication to consumers with regards to level four in this study.

The frame of reference contains not only the four levels of decision making described by McKinnon and Woodburn (1996), but also supplementary activities. Concerns regarding ecodesign and packaging (Colicchia et al., 2013; Perotti et al., 2012) were, indeed, one of the aspects that consumers communicated to e-tailers (1a in Figure 1). The focus of consumers on packaging materials and the size of the packages suggests that their environmental focus relates to the products, rather than to the services needed for them to receive the products, e.g. logistics and transportation. As for reverse logistics (e.g. Evangelista, 2014), we saw no communication 
linked to environmental aspects of this activity in any of the interfaces. On the contrary, in the communication from e-tailers to consumers, as well as from LSPs to e-tailers, returns were communicated solely as a selling argument and a service for consumers $(1 \mathrm{~b}$ and $2 \mathrm{~b}$ in Figure 1).

The results presented here show that it is not easy for consumers to make green distribution choices. One reason for this is the shortage of options for green distribution on the webpages of e-tailers, as such services can help consumers to make more environmentally sustainable choices (in line with Wiese et al., 2015). An issue that makes matters even more difficult for consumers is the lack of homogeneity between e-tailers. Not only are the green distribution alternatives labelled differently between different e-tailers, but also the green distribution activities available differ (such as climate offsets or distribution by train). A challenge for consumers is, consequently, to fully understand what it is they are purchasing.

Communication about green distribution between the three actors is deficient in all four interfaces shown in Figure 1. This is most evident in the interface between consumers and LSPs (2a and $2 \mathrm{~b}$ in Figure 1), where communication is very limited. The framework presented by Mohr and Nevin (1990) makes it clear that communication is of very different characters in the different interfaces. The frequency of the communication from e-tailers to consumers (1b in Figure 1) is low but common (every time the consumer makes a purchase), with very short duration (since the e-tailer has designed the website to achieve a quick check out). Interestingly, the frequency of the communication in the interface between LSPs and e-tailers ( $3 \mathrm{a}$ and $3 \mathrm{~b}$ in Figure 1) has the opposite characteristics, i.e. long duration and low frequency. The direction of communication is one-way between the consumers and e-tailers (1a and $1 \mathrm{~b}$ in Figure 1), while communication between e-tailers and LSPs ( $3 a$ and $3 b$ in Figure 1) is two-way, and comprises feedback and discussion. The level of formality is high in the communication from e-tailers to consumers ( $1 \mathrm{~b}$ in Figure 1), while it is less structured in the opposite direction (1b). The level of formality in the communication between LSPs and e-tailers ( $3 a$ and $3 b$ in Figure 1 ) is initially more formal (the LSPs describe their green distribution services) and becomes more personalised and informal in the most fruitful relations. With regards to content, our results show a lack of strive to change the behaviour of other actors, something also found in the general supply chain communication (see e.g. Richey, 2009). Only one interview provided insights into how the e-tailer changed the purchasing behaviour of consumers with respect to green distribution (by placing the green distribution alternative at the top of the list of services offered). However, when it comes to changing the consumers' beliefs and attitudes, one interesting idea was detected. As early as the purchasing stage of the process, we could, in our roles as fictive consumers, get a feeling of whether the e-tailer would offer green distribution alternatives. This initial feeling was often confirmed at checkout.

Cambra-Fierro and Polo-Redondo (2008) showed that a consequence of deficient communication is that buyers do not understand the capabilities of suppliers and suppliers do not understand the needs and expectations of buyers. One example can be seen in the issue of packaging. E-tailers sense a growing environmental interest in society in general and are targeted by consumer complaints regarding the use of plastic as packaging material, but seldom interpret these expectations and needs as "green". They see them as a need to exclude plastic. Another example arises when e-tailers do not understand the capability of LSPs, and demand technology that is not yet commercially available. A third example concerns whether e-tailers understand the green service purchased, as this has been developed in isolation by the LSPs. The LSPs interpret the customer need as "greener transport" and do not include "the understanding of that service and why it is green" as part of the service delivered, even though this is sometimes expected by the e-tailers. This example derives from E-tailer C, who has asked for a clearer description of green distribution from the LSP, but has not received more information: The representative from E-tailer C elaborates: "I would like to know in more detail 
what the service means. We have been given an introductory presentation and there is some more information on the LSP website, but I want to get a better overall picture of what their green distribution offer actually contains."

When exploring the communication between consumers, e-tailers and LSPs, several challenges arise. Identification of these challenges is an important point of departure when responding to the call for research made by Kembro et al. (2017), in which they request studies on how companies can overcome challenges in sharing information beyond the dyad. One challenge is that the e-tailer does not want the consumers to think about the environmental consequences of their consumption when they are seconds away from finalising their purchase. It is thus necessary to communicate green distribution in a way that makes this an easy and natural choice for the consumer. Further research of a more normative nature is needed to investigate how this can be done. We have seen one example of this: E-tailer $\mathrm{C}$ made the green distribution alternative the default selection and, in this way made environmental awareness the easiest choice. An interesting avenue for future research is to investigate how purchasing behaviour changes if the consumer must make an active choice not to be "green", instead of the present situation in which consumers often need to make an active choice to be "green". This may lead to segmentation of consumers, as not all consumers are in need of quick deliveries, in line with (Buldeo Rai et al., 2019b). This is also interesting from the perspective of consumer satisfaction, as e-commerce distribution affects the relationship between consumer perceptions of the online shopping experience and total customer satisfaction (Vakulenko et al., 2019). An area for further investigation is, thus, whether green distribution has a similar effect as e-commerce distribution in general.

Our findings show also that consumers have very little knowledge about the level of "greenness" of the distribution. This information remains with the LSPs, and is only communicated to the e-tailers to a limited extent. Kembro et al. (2017) described this effect, and suggested that the lack of information sharing is a result of the absence of a direct link between the LSPs and consumers. Further, interdependency between these two types of actors is low. Our findings suggest that the lack of information sharing can be explained by two of the factors that Kembro et al. (2017) suggested as critical: the degree of benefit sharing, and the quality of the information. This emphasises the important role that e-tailers must play in facilitating consumer influence on the greening of distribution. Another challenge that must be addressed in future research is to identify the dominant actor. Previous work has not given a clear answer regarding which actor has the power advantage in the interface between the etailer and the consumer, and who has the greatest possibility to influence the other actors. For example, Björklund et al. (2016) and Wiese et al. (2015) suggest that retailers have the power advantage, while Evans et al. (2017) and Meixell and Luoma (2015) emphasise the strength of demands from consumers. Consumers are seldom targeted in logistics research (see e.g. Abbasi and Nilsson, 2012; Bask et al., 2013), and we suggest that research to provide a better understanding of these actors' roles and power in greening distribution is required. Another area in which further research is needed concerns how the communication between consumers and LSPs can be strengthened.

This study has been limited to a Swedish context. Contextual parameters such as the environmental purchasing preferences of consumers, methods of communication used by retailers, the offer of several forms of delivery, the environmental status of infrastructure such as vehicles, and the design of distribution solutions for e-commerce differ between countries. We suggest, therefore, that similar studies in other countries should be conducted. Furthermore, studies are needed to understand how consumers interpret and experience the green distribution information provided on the websites of retailers, in order to guide the future development of service offerings. 


\section{Conclusions}

This paper has addressed the possibilities consumers have to influence the greening of distribution by exploring the communication between LSPs, e-tailers and consumers. We have studied green distribution activities related to the greening of logistics (e.g. Colicchia et al., 2013; Evangelista, 2014; McKinnon and Woodburn, 1996) and four facets of communication (Mohr and Nevin, 1990). Our results suggest that consumers at present have limited possibilities to influence the greening of distribution, and that one reason for this is the limited communication between LSPs, e-tailers and consumers concerning green distribution. One gap in communication, for example, appears because e-tailers control how distribution alternatives are presented on their websites, while it is the LSPs who develop and offer green distribution services. As communication between LSPs and consumers concerning green distribution does not take place, the information held by LSPs is not communicated to consumers.

This study is, to the best of our knowledge, the first to investigate the possibilities consumers have to influence green logistics in e-commerce. While Buldeo Rai et al. (2019b) focussed on the willingness of consumers to adopt green distribution alternatives, we have focussed on the possibilities that consumers have to use such alternatives. This study also adds to research that addresses the environmental effects of e-commerce and consumer behaviour, such as Pålsson et al. (2017) and van Loon et al. (2015). Those studies showed that consumer behaviour is an important factor that influences the magnitude of the environmental impact, but provided no guidance as to how to facilitate environmentally sound decisions from consumers. The study presented here is the first step towards an understanding of what is needed to facilitate such decisions. In a wider perspective of green logistics in general, our results suggest that research into consumer perspectives of green logistics (e.g. Abbasi and Nilsson, 2012; Meixell and Luoma, 2015) should be undertaken. This paper does, indeed, provide evidence that consumers can play an active role in the greening of logistics, but that they need guidance from e-tailers when doing so. This is compatible with suggestions made by Buldeo Rai et al. (2019b) and Wiese et al. (2015b). Our findings supplement these studies by showing that e-tailers have not come very far in this respect, at least not from the perspective of green distribution. This study is a response to a call for research into information sharing that goes beyond dyads (Kembro and Näslund, 2014). The inclusion of three actors (consumers, e-tailers and LSPs) provides a much deeper understanding of the roles played by various actors in the greening of distribution.

The managerial implications of this study lie in illustrating the important role that improved communication between the actors plays in the greening of distribution. Specifically, e-tailers can gain an increased understanding of their important role as facilitators of environmentally sound decisions for consumers through the design of their websites. Similarly, this study highlights the need for LSPs to support e-tailers in this work. It also suggests that LSPs must be more transparent about their green distribution alternatives, so that e-tailers and consumers can understand what these involve.

Finally, one can question whether consumers should play any role at all in the greening of distribution. Is this, instead, the responsibility of LSPs and e-tailers? Given the tremendous challenges of climate change, it is safe to say that all actors must be involved. In fact, it is possible that e-tailers will face additional challenges when consumer awareness increases, and consumers expect e-tailers to provide green distribution alternatives to a larger extent. Why not use this as a business opportunity also in the greening of distribution? Here lies a potential, as LSPs and e-tailers could jointly develop green services, bearing in mind that they must be easily understood by consumers. This link in communication between LSPs, e-tailers and consumers is largely lacking at present.

\section{References}


Abbasi, M. and Nilsson, F. (2012). "Themes and Challenges in Making Supply Chains Environmentally Sustainable". Supply Chain Management, Vol. 17, No. 5, pp. 517530.

Allen, J., Piecyk, M. and Piotrowska, M. (2017), "Analysis of Online Shopping and Home Delivery in the UK", University of Westminster, London.

Bask, A., Halme, M., Kallio, M. and Kuula, M. (2013). "Consumer Preferences for Sustainability and Their Impact on Supply Chain Management: The Case of Mobile Phones". International Journal of Physical Distribution \& Logistics Management, Vol., No. 5/6, pp. 380-406.

Browne, M., Rizet, C., Anderson, S., Allen, J. and Keita, B. (2005). "Life Cycle Assessment in the Supply Chain: A Review and Case Study". Transport Reviews, Vol. 25, No. 6, pp. 761-782.

Buldeo Rai, H. 2019. Environmental Sustainability of the Last Mile in Omnichannel Retail. Vrije Universiteit Brussel.

Buldeo Rai, H., Mommens, K., Verlinde, S. and Macharis, C. (2019a). "How Does Consumers' Omnichannel Shopping Behaviour Translate into Travel and Transport Impacts? Case-Study of a Footwear Retailer in Belgium". Sustainability, Vol. 11, No. 9.

Buldeo Rai, H., Verlinde, S. and Macharis, C. (2019b). "The "Next Day, Free Delivery" Myth Unravelled: Possibilities for Sustainable Last Mile Transport in an Omnichannel Environment". International Journal of Retail \& Distribution Management, Vol. 47, No. 1, pp. 39-54.

Cambra-Fierro, J. J. and Polo-Redondo, Y. (2008). "Creating Satisfaction in the DemandSupply Chain: The Buyers' Perspective". Supply Chain Management: An International Journal, Vol. 13, No. 3, pp. 211-224.

Colicchia, C., Marchet, G., Melacini, M. and Perotti, S. (2013). "Building Environmental Sustainability: Empirical Evidence from Logistics Service Providers". Journal of Cleaner Production, Vol. 59, pp. 197-209.

Edwards, J. B., McKinnon, A. C. and Cullinane, S. L. (2010). "Comparative Analysis of the Carbon Footprints of Conventional and Online Retailing: A "Last Mile" Perspective". International Journal of Physical Distribution \& Logistics Management, Vol. 40, No. 1/2, pp. 103-123.

Ehandelsindex. 2018. "Topplista: Topp 100 största nätbutikerna i Sverige", available at: http://www.ehandel.se/Topp-100-storsta-natbutikerna-i-Sverige,9706.html (accessed 15 March 2018).

Eurostat. 2020. "E-commerce statistics for individuals - Statistics Explained", available at: https://ec.europa.eu/eurostat/statistics-explained/pdfscache/46776.pdf (accessed 22 April 2020.

Evangelista, P. (2014). "Environmental Sustainability Practices in the Transport and Logistics Service Industry: An Exploratory Case Study Investigation". Research in Transportation Business \& Management, Vol. 12, pp. 63-72.

Evans, D., Welch, D. and Swaffield, J. (2017). "Constructing and Mobilizing 'the Consumer': Responsibility, Consumption and the Politics of Sustainability". Environment and Planning A, Vol. 49, No. 6, pp. 1396-1412.

Hübner, A., Kuhn, H. and Wollenburg, J. (2016). "Last Mile Fulfilment and Distribution in Omni-Channel Grocery Retailing: A Strategic Planning Framework". International Journal of Retail and Distribution Management, Vol. 44, No. 3, pp. 228-247.

Kembro, J. and Näslund, D. (2014). "Information Sharing in Supply Chains, Myth or Reality? A Critical Analysis of Empirical Literature". International Journal of Physical Distribution \& Logistics Management, Vol. 44, No. 3, pp. 179-200. 
Kembro, J., Näslund, D. and Olhager, J. (2017). "Information Sharing across Multiple Supply Chain Tiers: A Delphi Study on Antecedents". International Journal of Production Economics, Vol. 193, pp. 77-86.

Kohn, C. and Huge-Brodin, M. (2008). "Centralised distribution systems and the environment: how increased transport work can decrease the environmental impact of logistics". International Journal of Logistics: Research \& Applications, Vol. 11, No. 3, pp. 229-245.

Kotzab, H., Munch, H. M., de Faultrier, B. and Teller, C. (2011). "Environmental Retail Supply Chains: When Global Goliaths become Environmental Davids". International Journal of Retail \& Distribution Management, Vol. 39, No. 9, pp. 658-681.

Mangiaracina, R., Marchet, G., Perotti, S. and Tumino, A. (2015). "A Review of the Environmental Implications of B2C E-Commerce: A Logistics Perspective". International Journal of Physical Distribution \& Logistics Management, Vol. 45, No. 6, pp. 565-591.

Martinsen, U. and Huge-Brodin, M. (2014). "Environmental Practices as Offerings and Requirements on the Logistics Market". Logistics Research, Vol. 7, No. 1, pp. 1-22.

McKinnon, A. (2015), "Environmental Sustainability: A New Priority for Logistics Managers". In: Mckinnon, A., Browne, M., Piecyk, M. \& Whiteing, A. (eds.) Green Logistics: Improving the Environmental Sustainability of Logistics. 3rd ed, Kogan Page, London, UK.

McKinnon, A. C. and Woodburn, A. (1996). "Logistical Restructuring and Road Freight Traffic Growth". Transportation, Vol. 23, No. 2, pp. 141-161.

Meixell, M. J. and Luoma, P. (2015). "Stakeholder Pressure in Sustainable Supply Chain Management: A Systematic Review". International Journal of Physical Distribution and Logistics Management, Vol. 45, No. 1/2, pp. 69-89.

Miles, M. and Huberman, A. (1994). An Expanded Sourcebook: Qualitative Data Analysis, SAGE Publications, California, USA.

Mohr, J. and Nevin, J. R. (1990). "Communication Strategies in Marketing Channels: A Theoretical Perspective". Journal of Marketing, Vol. 54, No. 4, pp. 36-51.

Mohr, J. J. and Sohi, R. S. (1995). "Communication Flows in Distribution Channels: Impact on Assessments of Communication Quality and Satisfaction". Journal of Retailing, Vol. 71, No. 4, pp. 393-416.

Perotti, S., Zorzini, M., Cagno, E. and Micheli, G. J. L. (2012). "Green Supply Chain Practices and Company Performance: The Case of 3PLs in Italy". International Journal of Physical Distribution \& Logistics Management, Vol. 42, No. 7, pp. 640672.

Peters, L. D. and Fletcher, K. P. (2004). "Communication Strategies and Marketing Performance: An Application of the Mohr and Nevin Framework to IntraOrganisational Cross-Functional Teams". Journal of Marketing Management, Vol. 20, No. 7-8, pp. 741-770.

PostNord. 2019. "E-commerce in the Nordics - Six-month report 2019", available at: https://www.postnord.com/contentassets/9e5ef8a408834cb982f30f145a6b2208/en ehandeln-i-norden halvar 2019 highres.pdf.

Pålsson, H., Pettersson, F. and Hiselius, L. W. (2017). "Energy Consumption in E-Commerce Versus Conventional Trade Channels - Insights into Packaging, the Last Mile, Unsold Products and Product Returns". Journal of Cleaner Production, Vol. 164, pp. 765778.

Richey, J. R. G. (2009). "The Supply Chain Crisis and Disaster Pyramid: A Theoretical Framework for Understanding Preparedness and Recovery". International Journal of Physical Distribution \& Logistics Management, Vol. 39, No. 7, pp. 619-628. 
Sallnäs, U. (2016). "Coordination to Manage Dependencies between Logistics Service Providers and Shippers: An Environmental Perspective". International Journal of Physical Distribution \& Logistics Management, Vol. 46, No. 3, pp. 316-340.

Vakulenko, Y., Shams, P., Hellström, D. and Hjort, K. (2019). "Online Retail Experience and Customer Satisfaction: The Mediating Role of Last Mile Delivery". International Review of Retail, Distribution and Consumer Research, Vol. 29, No. 3, pp. 306-320.

van Loon, P., Deketele, L., Dewaele, J., McKinnon, A. and Rutherford, C. (2015). "A Comparative Analysis of Carbon Emissions from Online Retailing of Fast Moving Consumer Goods". Journal of Cleaner Production, Vol. 106, pp. 478-486.

van Loon, P., McKinnon, A. C., Deketele, L. and Dewaele, J. (2014). "The Growth of Online Retailing: A Review of its Carbon Impacts". Carbon Management, Vol. 5, No. 3, pp. 285-292.

Weijers, S., Glöckner, H.-H. and Pieters, R. (2012). "Logistic Service Providers and Sustainable Physical Distribution". Logistikdienstleister und Nachhaltige Distribution, Vol. 8, No. 2, pp. 157-165.

Wiese, A., Toporowski, W. and Zielke, S. (2015a). "Shopping Travel Behaviour: Influencing Factors, Shopper Types and Environmental Consequences". International Journal of Retail and Distribution Management, Vol. 43, No. 4-5, pp. 469-484.

Wiese, A., Zielke, S. and Toporowski, W. (2015b). "Sustainability in Retailing - Research Streams and Emerging Trends". International Journal of Retail \& Distribution Management, Vol. 43, No. 4/5.

Xiao, Z., Wang, J. J. and Liu, Q. (2018). "The Impacts of Final Delivery Solutions on EShopping Usage Behaviour: The Case of Shenzhen, China". International Journal of Retail \& Distribution Management, Vol. 46, No. 1, pp. 2-20.

Yrjölä, M., Saarijärvi, H. and Nummela, H. (2018). "The Value Propositions of Multi-, Cross-, and Omni-Channel Retailing". International Journal of Retail \& Distribution Management, Vol. 46, No. 11/12, pp. 1133-1152. 


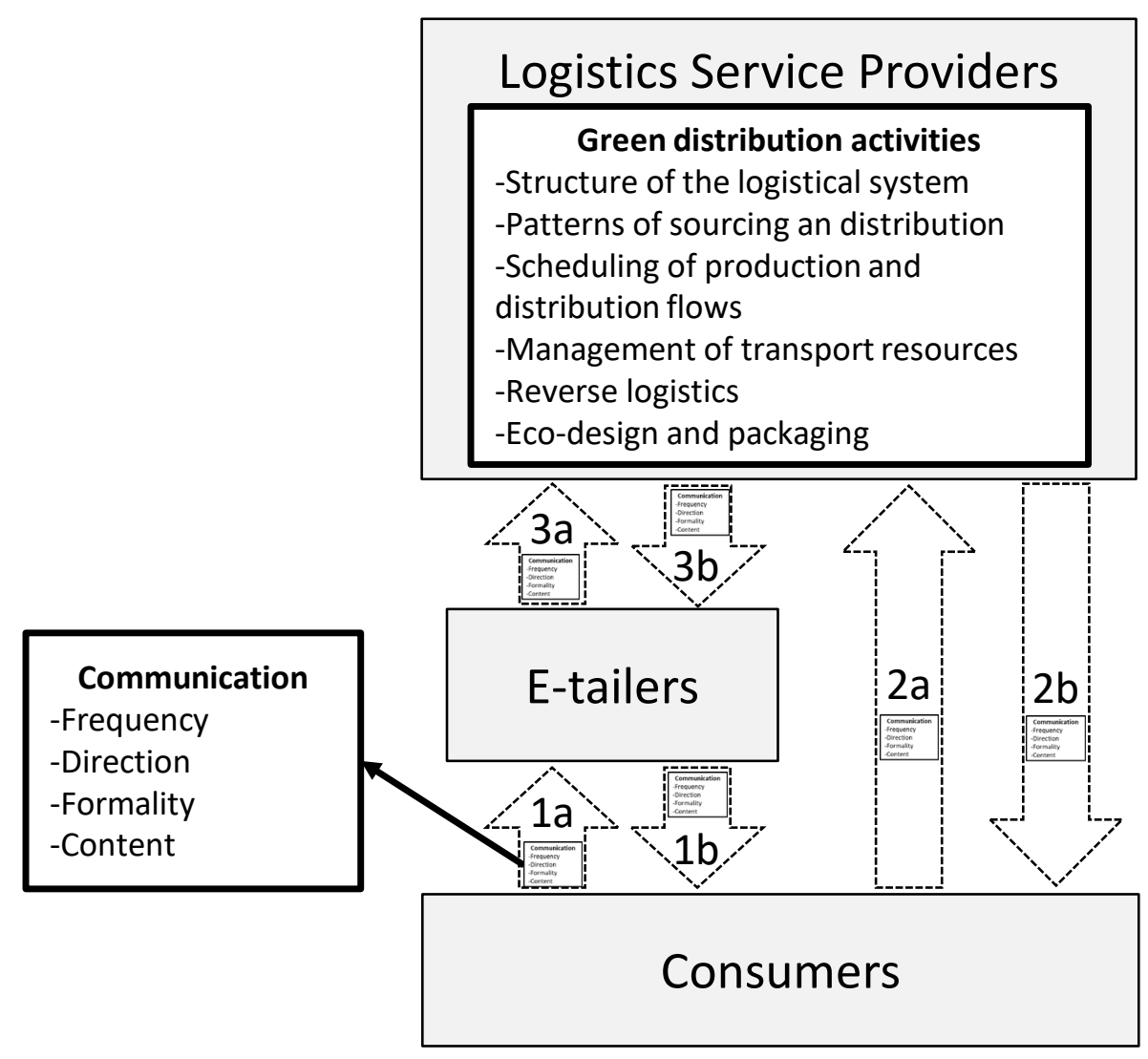

Figure 1: Six communication flows ( $1 a, 1 b, 2 a, 2 b, 3 a$, and $3 b)$ regarding green distribution activities operationalised by the LSPS. 
Table 1: The interviewed companies

\begin{tabular}{|l|l|l|}
\hline Company & Description & Respondents \\
\hline E-tailer A & Online pharmacy & Head of customer service \\
\hline E-tailer B & Online book store & Supply chain manager \\
\hline E-tailer C & $\begin{array}{l}\text { Makeup/beauty company with } \\
\text { physical stores as well as an online } \\
\text { sales channel }\end{array}$ & Head of e-commerce supply chain \\
\hline LSP A & Large global LSP & Sustainability manager \\
\hline LSP B & Large global LSP & $\begin{array}{l}\text { Market Manager, Consumer \& Retail and } \\
\text { Quality and Environmental Manager }\end{array}$ \\
\hline LSP C & $\begin{array}{l}\text { Swedish LSP with specific focus on } \\
\text { small parcel deliveries }\end{array}$ & Quality and Environmental Manager \\
\hline
\end{tabular}


Table 2: Facets of communication in the three studied interfaces

\begin{tabular}{|c|c|c|c|}
\hline & Consumer - e-tailer & E-tailer - LSP & Consumer - LSP \\
\hline Frequency & $\begin{array}{l}\text { Very low. Consumers only transfer } \\
\text { information in the purchasing moment. } \\
\text { Information to consumers is static and } \\
\text { seldom changed. }\end{array}$ & $\begin{array}{l}\text { Low in general. Management of transport } \\
\text { resources is a little higher, as e.g. retailers A } \\
\text { and C provide LSPs with daily order } \\
\text { information. }\end{array}$ & $\begin{array}{l}\text { Frequent exchange of information } \\
\text { limited to one aspect, namely the } \\
\text { time of delivery. The level of } \\
\text { duration is thus very low. }\end{array}$ \\
\hline Direction & $\begin{array}{l}\text { Both directions, but not as feedback and } \\
\text { dialogue. Instead, a one-way } \\
\text { communication that flows in two } \\
\text { directions. The e-tailer offers its services } \\
\text { and the consumer selects among these. }\end{array}$ & $\begin{array}{l}\text { Communication flows both ways, albeit not } \\
\text { always in a feedback loop. In general, LSPs } \\
\text { work isolated in development of services and } \\
\text { e-tailers respond with a simple } \\
\text { "interested/not interested". Some e-tailers } \\
\text { make environmental demands, but the LSPs } \\
\text { perceive a lack of understanding for realistic } \\
\text { demands. }\end{array}$ & $\begin{array}{l}\text { Both directions. Consumers can } \\
\text { sometimes choose preferred delivery } \\
\text { window, e.g. through a mobile } \\
\text { application. LSPs, in turn, can } \\
\text { provide consumers with up-to-date } \\
\text { information about the location of the } \\
\text { delivering vehicle. }\end{array}$ \\
\hline Formality & $\begin{array}{l}\text { High degree of formality, being planned } \\
\text { and routinized. One exception: } \\
\text { packaging. Here consumers are much } \\
\text { more active in their communication. } \\
\text { However, consumers are still struggling } \\
\text { to understand why some packages need } \\
\text { certain designs. E-tailers do not adapt to } \\
\text { the input from consumers. }\end{array}$ & $\begin{array}{l}\text { Mainly formal, illustrated by the LSPs' } \\
\text { offerings of standard solutions, or retailers' } \\
\text { demand for certain green distribution } \\
\text { activities (mainly linked to the management } \\
\text { of transport resources). An exception in a } \\
\text { specific relationship with two-way informal } \\
\text { and formal dialogue, and a strive to find new } \\
\text { more environmentally preferable solutions. }\end{array}$ & $\begin{array}{l}\text { Delivery-window information is well } \\
\text { structured and routinized and the } \\
\text { customers that are targeted receives it } \\
\text { in a planned and standardised way. }\end{array}$ \\
\hline
\end{tabular}




\begin{tabular}{|c|c|c|c|}
\hline Content & $\begin{array}{l}\text { E-tailers can use the information from } \\
\text { consumers to analyse trends in the } \\
\text { consumers' purchasing behaviour. This } \\
\text { can influence the design of future service } \\
\text { offerings. Direct communication that } \\
\text { influence consumer behaviour can e.g. } \\
\text { take place when e-tailers place the } \\
\text { environmental offering first in the list of } \\
\text { distribution offerings. }\end{array}$ & $\begin{array}{l}\text { Mainly indirect, where returns serve is a } \\
\text { good example. By charging for returns, the } \\
\text { LSPs have an indirect opportunity to } \\
\text { influence consumer behaviour The demands } \\
\text { of fuels and vehicles from retailers are } \\
\text { however examples of direct communication. }\end{array}$ & $\begin{array}{l}\text { Delivery-window information could } \\
\text { influence the consumer as it increases } \\
\text { the chance of the consumer being at } \\
\text { home at the time of delivery (i.e. } \\
\text { direct communication). The } \\
\text { environmental dimension is that it } \\
\text { decreases the risk that the LSP has to } \\
\text { e.g. deliver a second time, increasing } \\
\text { the environmental effects. }\end{array}$ \\
\hline
\end{tabular}

